\title{
Macroinvertebrate associated with macrophyte beds in a Cerrado stream
}

\author{
Renan de Souza Rezende ${ }^{1, *}$, Fernanda Silva Monção ${ }^{2}$ José Francisco Gonçalves Junior ${ }^{3}$ and \\ Anderson Medeiros dos Santos ${ }^{2}$
}

1 Program of Postgraduate in Environmental Science, Communitarian University of Chapecó Region, CEP: 89.809-000, Santa Catarina, Brazil.

2 Department of Biology, Institute of Biological Sciences, State University of Montes Claros, CEP: 39401-089 Montes Claros, Minas Gerais, Brazil.

3 AquaRiparia, Department of Ecology, University of Brasília - UnB, Campus Darcy Ribeiro, Asa Norte, CEP 70910-900, Brasília, DF, Brazil.

* Corresponding author: renanrezende30@gmail.com

Received: 12/12/17

Accepted: 22/11/18

\begin{abstract}
Macroinvertebrate associated with macrophyte beds in a Cerrado stream

Our aim was to determine the spatial (edge and center) and taxonomic influences of macrophyte beds of two species, Diamantina lombardii and Eriocaulon aquatile, on attributes, structure and functional feeding groups (FFG) of macroinvertebrate in a Brazilian savanna stream. A total of 29 invertebrate taxa were sampled, with the families Simuliidae and Chironomidae being most abundant. Diamantina lombardii exhibited greater density and richness of macroinvertebrates (2191 ind/g and 13 taxa, respectively) than E. aquatile (1217 ind/g and 8 taxa, respectively), which can be attributed to differences in leaf morphology (different resource and habitat availability). The habitat provided by $D$. lombardii favors better protection from the force of water current, which increases habitat dependence and facilitates macroinvertebrate colonization, whereas E. aquatile exhibited a greater number of exclusive taxa. Higher macroinvertebrate density also increased prey density, thereby explaining the greater abundance of predators found, mainly in the edge (by predation facilitation). Furthermore, spatial site in macrophyte beds can drive the composition of FFG by determining the availability and type of food resources. Filtering-collectors ( $25 \%)$ remove fine particles of organic matter from the water column, which explains their greater abundance at the edge of the beds. Gathering-collectors $(45 \%)$ consume organic matter obtained from the substrate and thus do not require water flow, which explains their greater density in the center of the beds. Therefore, macrophyte beds are important habitats that need to be conserved for the maintenance of macroinvertebrate biodiversity in Savannah streams.
\end{abstract}

Key words: Functional feeding groups, macroinvertebrate richness, cerrado stream, macrophytes, edge and center

\section{RESUMO}

\section{Macroinvertebrados em bancos de macrofictas}

Nosso objetivo foi determinar a influência do espaço (borda e centro) e especifica de banco de duas macrofitas (Diamantina lombardii e Eriocaulon aquatile) sobre os atributos das comunidades de macroinvertebrados, estrutura e grupo funcional trófico (GFT) em riacho de Cerrado. Encontramos um total de 29 taxa, onde Simuliidae e Chironomidae foram os macroinvertebrados mais abundantes. Maior densidade e riqueza de macroinvertebrados foram encontradas em D. lombardii, (2191 ind/g e 13 taxa, respectivamente) comparado a $\mathrm{E}$. aquatile (1217 ind/g e 8 taxa, respectivamente) devido a diferenças na morfologia foliar (mudanças no recurso e disponibilidade de habitat para a comunidade). A proteção da força de lavagem da água por $\mathrm{D}$. lombardii promove habitat específicos comprados a E. aquatile que pode facilitar a colonização dos macroinvertebrados. E. aquatile apresentou um alto numero de taxa exclusivos. A maior densidade aumenta a densidade de presas, ajudando a explicar as elevadas densidades de predadores na borda. A posição no banco de macrofita pode direcionar o GFT por 
mudanças no tipo e disponibilidade de recurso alimentar. Coletores-filtradores (25\%) removem partículas finas de matéria orgânica da coluna d'água, justificando sua maior abundancia na borda. Coletores-catadores (25\%) consomem matéria orgânica depositada no substrato sem precisar de corrente explicando a maior densidade no centro. Portanto, bancos de macrófitas são importantes habitats a serem conservados para a manutenção da biodiversidade de macroinvertebrados em riachos de Savana.

Palavras chave: Grupo trófico funcional, Riqueza de invertebrados, Riachos de Cerrado, Borda e centro

\section{INTRODUCTION}

The structure and distribution of macroinvertebrate communities in lotic systems can be determined by abiotic and biotic factors (Damanik-Ambarita et al., 2016; Merritt \& Cummins 1996; Tronstad et al., 2016). The most important abiotic factors of the aquatic habitat include geomorphology (mainly substrate type and matter input; Durães et al., 2016; Lobera et al., 2016; Rezende et al., 2014a), temperature (de Nadaï-Monoury et al., 2014), dissolved oxygen (Rezende et al., 2014b), flow discharge (Lobera et al., 2016), environmental quality (Damanik-Ambarita et al., 2016), and habitat heterogeneity (Heino et al., 2015a). For example, a greater presence of pebbles, gravel, and stones in the substrate can increase the biodiversity of macroinvertebrate communities by increasing habitat heterogeneity (Rezende et al., 2014b). On the other hand, increases in water physicochemical parameters, such as temperature and events of increased velocity of water current (by washing force), and decreases in dissolved oxygen and environmental quality, have negative effects on macroinvertebrate diversity (Lobera et al., 2016).

Studies investigating the effects of environmental factors (physical and chemical) on aquatic macroinvertebrate communities dominate the literature (Boyero et al., 2015; Ferreira et al., 2016; Ferreira et al., 2014; Heino et al., 2015b). However, biotic factors, such as the availability of food resources (prey abundance and plant resource input; Mora-Gómez et al., 2016; Rezende et al., 2016) and biological interactions (e.g. competition and predation), can also drive macroinvertebrate community structure, (Fenoglio et al., 2016; Rezende et al., 2015; Rodriguez-Lozano et al., 2016). As example of biologi- cal interactions, macroinvertebrate communities are important sources of food for fish, while invertebrate communities themselves (Greenway et al., 2014; Rezende et al., 2015) can participate directly in plant litter decomposition in lotic systems (Gonçalves et al., 2016; Rezende et al., 2016), showing their potential for complex interactions within lotic habitats (Durães et al., 2016).

The presence of macrophytes is important for promoting the diversity and distribution of macroinvertebrates (Damanik-Ambarita et al., 2016; Mykra et al., 2008). Aquatic macrophytes constitute an important habitat for macroinvertebrate communities by providing shelter from predators and water current (Baker et al., 2016; Mykra et al., 2008; Padial et al., 2014; Thomaz \& Cunha, 2010), and a source of food (feeding directly on leaf tissue and/or periphyton). Different macrophyte species represent different habitats due to differences in plant architecture and the organic resources they provide through trapping detritus in microhabitats (Tessier et al., 2008; Thomaz \& Cunha, 2010). This variation in habitat provided by macrophyte species diversity can provide a diverse range of habitat characteristics that can structure the complexity of macroinvertebrate communities differently (Tessier et al., 2008; Thomaz \& Cunha, 2010).

Submerged macrophytes are usually more morphologically complex in plant architecture and surface area than emergent macrophytes (Thomaz \& Cunha, 2010). The lower complexity of emergent macrophytes may support macroinvertebrate communities with less biomass and different species composition and size structure than submerged macrophytes (Tessier et al., 2008). On the other hand, higher primary productivity has been associated with emergent and floating macrophytes than with submerged macrophytes (Lycarião \& Dantas, 2017). Macrophyte 
productivity can have a positive influence on macroinvertebrate communities (Damanik-Ambarita et al., 2016; Mykra et al., 2008). However, abiotic factors can also affect the distribution of macrophytes and macroinvertebrates (Christoffersen, 2008; Thomaz \& Cunha, 2010). For example, increased water turbid may decrease submerged plant density, and increase the importance of other plant types, such as emergent and floating macrophytes (Christoffersen, 2008; Thomaz \& Cunha, 2010). Furthermore, nutrient concentrations of the water are important factors for floating macrophytes, whereas sediments are important for rooted and submerged macrophytes (Lycarião \& Dantas, 2017).

Some characteristics of macrophytes can affect their associated macroinvertebrates, such as the leaf architecture (leaf morphology; Quintão et al., 2013), growth habit (Thomaz \& Cunha 2010), chemical composition (nutrient concentration and secondary compounds; Jardine, 2014) and the presence of an epiphytic community (Baker et al., 2016; Tronstad et al., 2016). The spatial site within macrophyte beds can also change abiotic and biotic influences and the availability of resources for macroinvertebrate communities (Harrison et al., 2004; Sychra et al., 2010). For example, the gradient of decreased fine particulate matter and increased periphyton biomass from edge to center, due to the decreased force of water flow, can influence the macroinvertebrate community. Some studies have investigated the ecological role of macrophytes in the Neotropical region, and the effect of spatial site within macrophyte beds (Ali et al., 2007; Carvalho et al., 2015; Quintão et al., 2013; Thomaz \& Cunha, 2010); however, such information is incipient.

In the present study, we evaluated the macroinvertebrate communities on submerged (Diamantina lombardii) and emergent (Eriocaulon aquatile) macrophyte beds fixed in the substrate of a Neotropical stream system in the cerrado (Brazilian savanna). The submerged macrophytes were morphologically more complex (Thomaz \& Cunha, 2010), while the emergent macrophytes had greater primary productivity (Lycarião \& Dantas, 2017). Additionally, abiotic factors, such as water turbidity and solar radiation, can have different effects on submerged plants, while underwater radiation is the way of life for submerged macrophytes (Lycarião \& Dantas, 2017). Therefore, our first hypothesis is that species of macrophytes are more important to determine the density and richness of macroinvertebrate compared to beds site into the macrophytes plants. However, if the decreased water current discharge will decrease fine particulate matter and increase periphyton biomass along the gradient from the edge to the center, our second hypothesis is an increase in abundance of gathering-collectors and a decrease of filtering-collectors along the gradient from the edge to center. To test the first hypothesis we analyzed the density and richness of macrophytes. To test our second hypothesis, we evaluated the distribution of functional feeding groups between spatial sites on macrophytes (edge and center). In this way, we will be able to determine the spatial (edge and center) and taxonomic $(D$. lombardii and $E$. aquatile) influence of macrophyte beds on macroinvertebrate community attributes and structure in a cerrado stream.

\section{MATERIAL AND METHODS}

\section{Study area}

The study was conducted in the Boleiras stream, a first-order stream located in Rio Preto State Park in the state of Minas Gerais, Brazil ( $18^{\circ} 07^{\prime}$ $04^{\prime \prime} \mathrm{S}, 43^{\circ} 20^{\prime} 42^{\prime \prime} \mathrm{W}$ ). The stream is located in the upper region of Jequitinhonha Valley in the Espinhaço Mountain complex, which has an average elevation of 800 meters. The climate regime is tropical AW-type (with a dry winter) with a rainy season from November to March (average rainfall of $223 \mathrm{~mm}$ ) and a dry season from June to August (average rainfall of $8 \mathrm{~mm}$; http://hidroweb.ana.gov.br).

\section{Physical and chemical parameters of the water}

A multianalyzer (model 85, YSI Inc.) was used to measure in situ temperature, electrical conductivity, $\mathrm{pH}$ (YSI's EcoSense pH100A), and dissolved oxygen, on each sampling occasion. To calculate discharge, water current velocity was measured with a flow meter (Sigma Sports model FP101, 
Global Water) and depth and width with measuring tapes, both also on each sampling occasion.

\section{Macrophyte beds}

Two homogeneous macrophyte beds of species with different architectural patterns - Diamantina lombardii (Podostemaceae) and Eriocaulon aquatile (Eriocaulaceae) - were chosen for study. Diamantina lombardii has digitate leaves (distichous, simple, digitate, 3-8 segments) and a prominent gynophore. Plants are vegetative when immersed by high water (submerged, fixed, living in small rivers and streams), and flower with receding water levels, with the capsules maturing on dry rocks and subsequently dispersed; seasonal water level fluctuations are thus central to the ecology of these plants. The species occurs in only two lotic systems, the Preto River and the Peixe River, in the "Parque Estadual do Rio Preto" conservation unit (Rutishauser et al., 2005). Eriocaulon aquatile has a rhizome or short stem, is membraneous, and has leaves with 3-5 ribs; 1-3 scapes; staminate and pistillate flowers with sepals smaller than petals in mature capitula and staminate flowers with equal petals. The species has a broad geographic distribution in the Atlantic Forest and Cerrado, and occurs submerse and fixed in small rivers and streams in the conservation units of "Parque Estadual do Rio Preto" and "Parque Nacional da Serra do Cipó" (APGII, 2003).

\section{Sampling of macroinvertebrates associated with aquatic macrophyte beds}

Sampling was conducted monthly from August 2011 to July 2012 (12 months). Five macrophyte beds of similar size were selected for each of the two macrophyte species. Each macrophyte bed was sampled with a Surber collector $\left(0.01 \mathrm{~m}^{2}\right)$ at two spatial sites (edge and center). Thus, sampling encompassed: two macrophyte species $\mathrm{x}$ two bed sites $\mathrm{x}$ five beds $\mathrm{x} 12$ months $=240$ sub-replicate samples; Fig. S1, available at http://www.limnetica.net/en/limnetica.

In the laboratory, the macrophyte beds were washed with distilled water in a sieve $(250 \mu \mathrm{m}$ mesh). The invertebrates retained were fixed in
$70 \%$ alcohol for later sorting and identification (Hamada et al., 2014; Merritt \& Cummins 1996). The number of taxa (taxonomic richness) and density (individual/ to $\mathrm{m}^{2}$ ) were calculated based on the invertebrate inventory. The invertebrates were also classified into five functional feeding groups (FFGs): gathering-collectors, filtering-collectors, shredders, scrapers and predators (Cummins et al., 2005; Pérez 1988).

\section{Statistical analysis}

To evaluate the effects of macrophyte bed taxa on density, richness and FFGs of macroinvertebrates, we used generalized linear models (GLM), with Gaussian (link= log, test= F), Poisson (link $=\log$, test $=$ Chi-square) and quasi-binomial (link $=$ logit, test $=$ Chi-square) distributions, respectively (Crawley, 2007). Data for density and richness (response variables) were analyzed in terms of macrophyte species $(D$. lombardii and E. aquatile), site in the beds (edge and center) and the interaction between these two factors (two GLMs). To evaluate the influence of spatial site in the beds of the two macrophyte species on the FFGs of aquatic macroinvertebrates, five GLMs were constructed (one for each FFG: gathering-collectors, filtering-collectors, scrapers, shredders and predators). All GLMs analyzed were corrected for cases of under- or overdispersion. A linear regression was used to evaluate relationships between water velocity and density, richness and FFG of macroinvertebrates (Crawley, 2007).

To analyze the overall effects of macrophyte species (D. lombardii and E. aquatile), site in the beds (edge and center) and the interaction between these two factors on the structure of the macroinvertebrate community, PerMANOVA and par-contrast analyses (Bonferroni correction) were used (Oksanen et al., 2013; Oksanen et al., 2008). A Correspondence Analysis (CA) was carried out to search for patterns in the distribution of aquatic macroinvertebrates between the edge and center of the beds of the two macrophyte species (Oksanen et al., 2013; Oksanen et al., 2008). Ordination of sampling sites, based on the density of macroinvertebrates, was performed to reduce the dimensionality of biotic data. 
Table 1. Mean and standard error values of the density of macroinvertebrates (individuals $/ \mathrm{m}^{2}$ ) in the sampling sites (edge and center) and macrophytes species (D. lombardii and E. aquatile). Media e erro padrão dos valores de densidade de macroinvertebrados (individuos $/ \mathrm{m}^{2}$ ) nos pontos amostrados (borda and centro) e espécie de macrofita (D. lombardii and E. aquatile).

\begin{tabular}{|c|c|c|c|c|c|c|c|c|c|c|c|c|}
\hline & \multicolumn{6}{|c|}{ D. lombardii } & \multicolumn{6}{|c|}{ E. aquatile } \\
\hline & \multicolumn{3}{|c|}{ Edge } & \multicolumn{3}{|c|}{ Center } & \multicolumn{3}{|c|}{ Edge } & \multicolumn{3}{|c|}{ Center } \\
\hline & Mean & & $\mathrm{SE}$ & Mean & & SE & Mean & & $\mathrm{SE}$ & Mean & & SE \\
\hline $\begin{array}{l}\text { Annelida } \\
\text { Oligochaeta }\end{array}$ & 1282.4 & \pm & 4.4 & 2728.1 & \pm & 5.3 & 3328.6 & \pm & 6.2 & 4220.7 & \pm & 7.1 \\
\hline $\begin{array}{l}\text { Arthropoda } \\
\text { Arachnida }\end{array}$ & & & & & & & & & & & & \\
\hline $\begin{array}{l}\text { Hydracarina } \\
\text { Insecta }\end{array}$ & 88.2 & \pm & 1.1 & 162.5 & \pm & 1.4 & 128.6 & \pm & 2.1 & 112.1 & \pm & 1.3 \\
\hline Ephemeroptera & & & & & & & & & & & & \\
\hline Baetidae & 2014.7 & \pm & 4.2 & 3003.1 & \pm & 4.6 & 2533.9 & \pm & 4.4 & 2412.1 & \pm & 4.7 \\
\hline Leptohyphidae & 67.6 & \pm & 1.3 & 121.9 & \pm & 1.7 & 60.7 & \pm & 1.2 & 225.9 & \pm 2 & 2.5 \\
\hline Leptophlebiidae & 185.3 & \pm & 1.8 & 384.4 & \pm & 2.5 & 487.5 & \pm & 2.4 & 560.3 & \pm 2 & 2.9 \\
\hline Odonata & & & & & & & & & & & & \\
\hline Libellulidae & 70.6 & \pm & 1.0 & 125.0 & \pm & 1.3 & 119.6 & \pm & 1.4 & 137.9 & \pm & 1.7 \\
\hline Gomphidae & 2.9 & \pm & 0.4 & 0.0 & \pm & 0.0 & 5.4 & \pm & 0.5 & 0.0 & \pm & 0.0 \\
\hline Aeshnidae & 0.0 & \pm & 0.0 & 0.0 & \pm & 0.0 & 1.8 & \pm & 0.4 & 0.0 & \pm & 0.0 \\
\hline Calopterygidae & 0.0 & \pm & 0.0 & 0.0 & \pm & 0.0 & 1.8 & \pm & 0.4 & 0.0 & \pm & 0.0 \\
\hline Plecoptera & & & & & & & & & & & & \\
\hline Perlidae & 0.0 & \pm & 0.0 & 0.0 & \pm & 0.0 & 3.6 & \pm & 0.4 & 0.0 & \pm & 0.0 \\
\hline Hemiptera & & & & & & & & & & & & \\
\hline Veliidae & 2.9 & \pm & 0.4 & 0.0 & \pm & 0.0 & 0.0 & \pm & 0.0 & 0.0 & \pm & 0.0 \\
\hline Megaloptera & & & & & & & & & & & & \\
\hline Corydalidae & 47.1 & \pm & 0.9 & 59.4 & \pm & 0.8 & 48.2 & \pm & 0.8 & 55.2 & \pm & 0.9 \\
\hline Hydrobiosidae & 200.0 & \pm & 1.4 & 275.0 & \pm & 1.5 & 141.1 & \pm & 1.3 & 156.9 & \pm & 1.3 \\
\hline Hydroptilidae & 11.8 & \pm & 0.6 & 28.1 & \pm & 0.8 & 32.1 & \pm & 1.0 & 34.5 & \pm & 1.1 \\
\hline Hydropsychidae & 5773.5 & \pm & 9.4 & 3871.9 & \pm & 6.6 & 3692.9 & \pm & 8.0 & 4598.3 & \pm & 7.2 \\
\hline Philopotamidae & 5.9 & \pm & 0.5 & 9.4 & \pm & 0.5 & 1.8 & \pm & 0.4 & 6.9 & \pm & 0.6 \\
\hline Leptoceridae & 123.5 & \pm & 1.4 & 128.1 & \pm & 1.3 & 75.0 & \pm & 1.1 & 67.2 & \pm & 1.2 \\
\hline Lepidoptera & & & & & & & & & & & & \\
\hline $\begin{array}{l}\text { Pyralidae } \\
\text { Coleoptera }\end{array}$ & 58.8 & \pm & 1.3 & 68.8 & \pm & 1.2 & 5.4 & \pm & 0.5 & 17.2 & \pm & 1.1 \\
\hline Dryopidae & 208.8 & \pm & 1.9 & 150.0 & \pm & 1.7 & 32.1 & \pm & 1.0 & 55.2 & \pm & 1.5 \\
\hline Dytiscidae & 2.9 & \pm & 0.4 & 3.1 & \pm & 0.4 & 1.8 & \pm & 0.4 & 3.4 & \pm & 0.4 \\
\hline Elmidae & 12679.4 & \pm & 8.7 & 13909.4 & \pm & 8.3 & 10537.5 & \pm & 7.3 & 11665.5 & \pm & 8.6 \\
\hline Hydroscaphidae & 0.0 & \pm & 0.0 & 37.5 & \pm & 1.3 & 21.4 & \pm & 0.8 & 12.1 & \pm & 0.6 \\
\hline Scirtidae & 35.3 & \pm & 1.0 & 37.5 & \pm & 0.9 & 69.6 & \pm & 1.3 & 44.8 & \pm & 1.1 \\
\hline Psephenidae & 0.0 & \pm & 0.0 & 0.0 & \pm & 0.0 & 1.8 & \pm & 0.4 & 0.0 & \pm & 0.0 \\
\hline Diptera & & & & & & & & & & & & \\
\hline Ceratopogonidae & 300.0 & \pm & 1.9 & 503.1 & \pm & 2.2 & 501.8 & \pm & 2.6 & 450.0 & \pm & 2.3 \\
\hline Chironomidae & 12414.7 & \pm & 10.6 & 13812.5 & \pm & 13.2 & 3685.7 & \pm & 6.3 & 3443.1 & \pm & 5.8 \\
\hline Empididae & 117.6 & \pm & 1.3 & 137.5 & \pm & 1.1 & 89.3 & \pm & 1.2 & 115.5 & \pm & 1.3 \\
\hline Simuliidae & 21126.5 & \pm & 14.9 & 44687.5 & \pm & 26.0 & 31766.1 & \pm & 17.0 & 32413.8 & \pm & 16.5 \\
\hline Dolichopodidae & 0.0 & \pm & 0.0 & 0.0 & \pm & 0.0 & 1.8 & \pm & 0.4 & 1.7 & \pm & 0.4 \\
\hline Mean & 1959 & \pm & 2.4 & 2905 & \pm & 2.9 & 1978 & \pm & 2.4 & 2096 & \pm & 2.5 \\
\hline Total & 56820 & & & 84243 & & & 57376 & & & 60810 & & \\
\hline
\end{tabular}




\section{RESULTS}

Mean water velocity was $1.28 \mathrm{~m} / \mathrm{s}( \pm 0.98)$, with higher values for the edge of the beds of $D$. lombardii $(1.97 \pm 0.84 \mathrm{~m} / \mathrm{s})$ and $E$. aquatile $(1.46 \pm 0.71 \mathrm{~m} / \mathrm{s})$, followed by the center of $E$. aquatile $(1.06 \pm 0.43 \mathrm{~m} / \mathrm{s})$ and the center of $D$. lombardii $(0.61 \pm 0.43 \mathrm{~m} / \mathrm{s})$. An opposite pattern was observed for depth in the macrophyte beds, with the higher values for the edge of $D$. lombardii $(10.3 \pm 1.41 \mathrm{~cm})$ and E. aquatile $(9.72 \pm 1.81$ $\mathrm{cm})$, followed by the center of $D$. lombardii $(5.97 \pm 1.09 \mathrm{~cm})$ and the center of E. aquatile $(5.16 \pm 0.93 \mathrm{~cm})$. Temperature ranged from 18 to $22{ }^{\circ} \mathrm{C}$ for the water, and 16 to $23^{\circ} \mathrm{C}$ for the air. Water $\mathrm{pH}$ was near neutral (range 6.1 to 6.65), with low electrical conductivity (range 3.02 to $11.45 \mu \mathrm{S} / \mathrm{cm}$ ) but high levels of dissolved oxygen (range 8.45 to $10.03 \mathrm{mg} / \mathrm{L}$ ).

A total of 29 macroinvertebrate taxa (Table 1) were found representing three classes: Insecta (nine orders) Clitellata (one subclass), and Arachnida). The most abundant invertebrate families, considering both macrophyte species together, were Simuliidae (Diptera), followed by Elmidae (Coleoptera) and Chironomidae (Diptera), all of Insecta. Considering macrophyte species separately, the pattern was similar for $D$. lombardii (Podostemaceae), but not for the $E$. aquatile (Eriocaulaceae) beds, which had Hydropsychidae (Trichoptera) replacing Chironomidae as the third most abundant taxon (Table 1). Furthermore, the families Dolichopodidae (Diptera), Psephenidae (Coleoptera), Perlidae (Plecoptera), Aeshnidae (Odonata) and Calopterygidae (Odonata) were found only in $E$. aquatile, while Veliidae (Hemiptera) was found exclusively in D. lombardii.

Macroinvertebrate community composition differed between spatial sites in macrophyte beds (edge and center), with some taxonomical groups (Veliidae, Gomphidae (Odonata), Psephenidae, Perlidae, Aeshnidae and Calopterygidae) being exclusive to the edge while none of the taxa were exclusive to the center (Table 1). Macrophyte species had a significant effect on density and richness of macroinvertebrate communities (Table 2A). Spatial site (edge and center) did not have a significant effect on density and richness of the macroinvertebrate communities (Table 2A).

Both density and richness were significantly higher in D. lombardii than in E. aquatile (Table 2A). Sites within macrophyte beds did not differ significantly in density and richness of aquatic macroinvertebrates (Table 2A; Fig. 1). Water velocity was negatively related to richness (linear regression $\left.\mathrm{R}^{2}{ }_{(1,22)}=-0.72, p=0.048\right)$ and density of invertebrates (linear regression $\left.\mathrm{R}^{2}{ }_{(1,22)}=-0.79, p=0.017\right)$. With regard to FFGs, there was greater relative abundance of predators and gathering-collectors in the center, while filtering-collectors were more abundant in the edge of $D$. lombardii beds (Table 2B). The relative abundances of the other FFGs did not vary significantly among the factors tested (Table 2B; Fig. 2). Water velocity was negatily related to abundance of predator (linear regression $\left.\mathrm{R}^{2}(1,22)=-0.69, p<0.001\right)$. The FFGs abundance of gathering-collectors $\left(\mathrm{R}^{2}(1,22)=\right.$ $-0.11, p=0.891)$, filtering-collectors $\left(\mathrm{R}^{2}(1,22)=\right.$ $-0.26, p=0.548)$, scrapers $\left(\mathrm{R}^{2}(1,22)=-0.13, p=\right.$ $0.772)$ and shredders $\left(\mathrm{R}^{2}(1,22)=0.21, p=\right.$ $0.734)$ were not significantly related to water velocity.

According to PERMANOVA, the structure of the aquatic macroinvertebrate community (based on occurrence and density) exhibited a pattern similar to that observed for richness and density (Table 2C), with the macroinvertebrate community varying only between macrophyte species (Table 2C). In the Correspondence Analysis (CA), Axis 1 (29.8\%) and Axis 2 (18.2\%), with eigenvalues of 0.20 and 0.12 , respectively, explained $48 \%$ of the total of variance. The aquatic macroinvertebrates were ordinated according to their occurrence and density on the different macrophyte species, but not according to their site within the macrophyte beds (edge and center). Thus, the macrophyte species could only be distinguished by the presence of Veliidae, Dytiscidae, Dryopidae and Chironomidae on $D$. lombardii, and Simuliidae, Dolichopodidae, Psephenidae, Aeshnidae and Calopterygidae on E. aquatile. On the other hand, the structure of the aquatic macroinvertebrate communities did not segregate between the edge and center of beds (Fig. 3). 
Table 2. Generalized Linear Models (GLM) comparing (1) the effect of sites (edge and center) and macrophyte species (D. lombardii and E. aquatile) on the density and richness of the macroinvertebrate community; (2) the effect of sites on the percentage of the five functional feeding group (shredders, predators, gathering-collectors, filtering-collectors and scrapers); (3) the effect of sites and macrophyte species on macroinvertebrates composition. Also contrast analysis of GLMs and PerMANOVA results. Degrees of freedom (DF) and Deviance Residual (DR \%). Modelos Lineares Generalizados (MLG) comparando (1) efeito do local (borda e centro) e espécie de macrofita (D. lombardii e E. aquatile) sobre a densidade e riqueza da comunidade de macroinvertebrados; (2) efeito do local sobre a percentagem dos cinco grupos funcionais troficos (fragmentadores, predadores, coletores-catadores, coletores-filtradores e raspadores); (3) efeito do local e espécie de macrofita sobre a composição de macroinvertebrados. Analise de contraste dos MLGs e resultado da PerMANOVA

\begin{tabular}{|c|c|c|c|c|}
\hline Test & DF & DR \% & $P$ & Result \\
\hline \multicolumn{5}{|c|}{ A - Factorial Two Way GLMs } \\
\hline Site & 1 & 0.75 & 0.123 & \\
\hline Macrophyte & 1 & 7.93 & $<0.001$ & E. aquatile $>$ D. lombardii \\
\hline Site*Macrophyte & 1 & 1.27 & 0.041 & \\
\hline Residual & 235 & 90.05 & & \\
\hline \multicolumn{5}{|l|}{ Richness } \\
\hline Site & 1 & 0.02 & 0.78 & \\
\hline Macrophyte & 1 & 7.18 & $<0.001$ & E. aquatile $>$ D. lombardii \\
\hline Site*Macrophyte & 1 & 0.17 & 0.401 & \\
\hline Residual & 235 & 92.62 & & \\
\hline \multicolumn{5}{|c|}{ B - One Way GLMs } \\
\hline \multicolumn{5}{|c|}{ Shredders $\%$} \\
\hline \multicolumn{5}{|l|}{ D. lombardii } \\
\hline Site & 1 & 0.83 & 0.463 & \\
\hline Residual & 65 & 99.17 & & \\
\hline \multicolumn{5}{|l|}{ E. aquatile } \\
\hline Site & 1 & 0.08 & 0.718 & \\
\hline Residual & 171 & 99.92 & & \\
\hline \multicolumn{5}{|l|}{ Predators \% } \\
\hline \multicolumn{5}{|l|}{ D. lombardii } \\
\hline Site & 1 & 9.29 & $<0.001$ & edge $>$ center \\
\hline Residual & 65 & 90.71 & & \\
\hline \multicolumn{5}{|l|}{ E. aquatile } \\
\hline Site & 1 & 0.21 & 0.551 & \\
\hline Residual & 171 & 99.79 & & \\
\hline \multicolumn{5}{|c|}{ Gathering-Collectors \% } \\
\hline \multicolumn{5}{|l|}{ D. lombardii } \\
\hline Site & 1 & 4.11 & 0.049 & edge $>$ center \\
\hline Residual & 65 & 95.89 & & \\
\hline \multicolumn{5}{|l|}{ E. aquatile } \\
\hline Site & 1 & 0.07 & 0.956 & \\
\hline Residual & 171 & 99.93 & & \\
\hline \multicolumn{5}{|c|}{ Filtering-Collectors \% } \\
\hline \multicolumn{5}{|c|}{ D. lombardii } \\
\hline Site & 1 & 4.37 & 0.048 & center $>$ edge \\
\hline Residual & 65 & 95.63 & & \\
\hline \multicolumn{5}{|l|}{ E. aquatile } \\
\hline Site & 1 & 0.17 & 0.584 & \\
\hline Residual & 171 & 99.83 & & \\
\hline \multicolumn{5}{|l|}{ Scrapers \% } \\
\hline \multicolumn{5}{|l|}{ D. lombardii } \\
\hline Site & 1 & 1.47 & 0.326 & \\
\hline Residual & 65 & 98.53 & & \\
\hline \multicolumn{5}{|l|}{ E. aquatile } \\
\hline Site & 1 & 0.19 & 0.572 & \\
\hline Residual & 171 & 99.81 & & \\
\hline \multicolumn{5}{|c|}{ C - Two Way PerMANOVA } \\
\hline Site & 1 & 0.66 & 0.611 & \\
\hline Macrophyte & 1 & 5.57 & $<0.001$ & E. aquatile $\neq D$. lombardii \\
\hline Site*Macrophyte & 1 & 0.06 & 0.921 & \\
\hline Residual & 235 & 93.71 & & \\
\hline
\end{tabular}



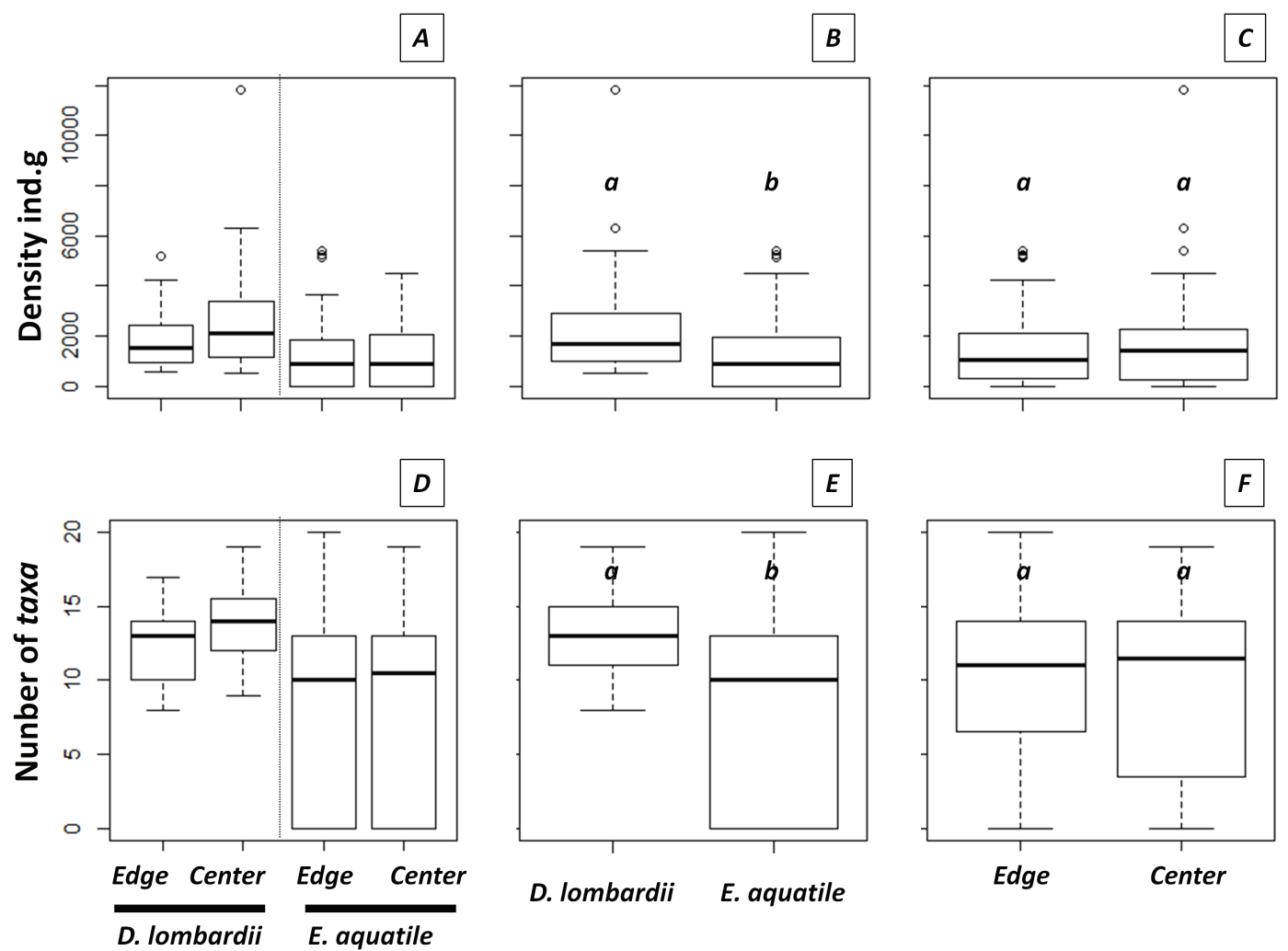

Figure 1. Density (A, B and C) and number of taxa (richness; D, E and F) of macroinvertebrates in edge and center (C and F) of D. lombardii and E. aquatile macrophytes beds (B and E). First (lower line) and third (higher line) quartile, the median (bold line), upper and lower limits (dashed line) and outliers (circles). Different letters (a and b) indicate significant differences. Densidade (A, $B e C$ ) $e$ numero de taxa (riqueza; $D, E$ e F) de macroinvertbrados na borda e centro (C e F) em bancos de D. lombardii $e$ E. aquatile (B e E). Primeiro (linha inferior) e terceiro quartil (linha superior), média (linha em negrito), limites superior e inferior (linha tracejada) e valores discrepantes (circulos). Letras diferentes (A e B) indicam diferenças significativas.

\section{DISCUSSION}

Macrophyte species was to be more important for the density and richness of the macroinvertebrate communities than the site within the beds. Differences in leaf morphology between $D$. lombardii and Eriocaulon aquatile (Balci \& Kennedy 2003; Warfe \& Barmuta 2006) resulted in different dissectedness and surface area (Gonçalves et al., 2012; Quintão et al., 2013), and thus explains the differences in their macroinvertebrate communities (Heino et al., 2015b). Furthermore, nutrient and chemical composition of leaf tissue (Carvalho et al., 2015; Gonçalves et al., 2016; Rezende et al., 2016) are important for the colonization of periphyton and epiphytic communities, which enrich the substrate as a resource for invertebrate communities (Baker et al., 2016; Rosa et al., 2013). The greater leaf complexity and nutritional composition (e.g. nitrogen and phosphorus) of $D$. lombardii may explain its greater macroinvertebrate density and richness compared to $E$. aquatile, thus corroborating our first hypothesis. Therefore, this result may indicate that the taxonomic identity of macrophytes can drive macroinvertebrate community colonization in cerrado streams. The specific habitat of $D$. lombardii (submerged and fixed in small swift currents) may provide shelter against high current velocity, compared to E. aquatile (emergent and fixed in less current), and which may also increase habitat dependence and facilitate colonization by macroinvertebrates (Choi et al., 2014; Rezende et al., 2014a). 

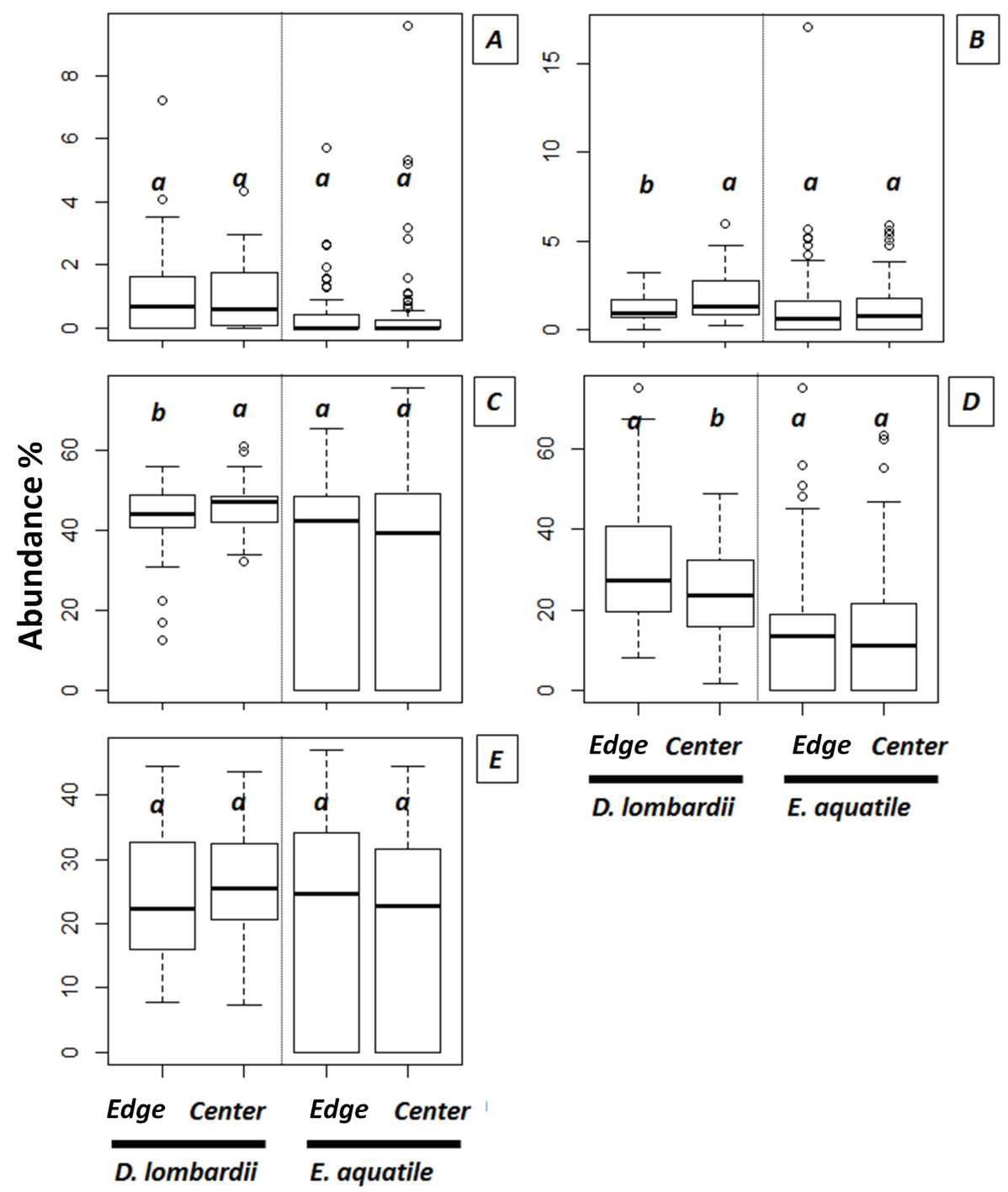

Figure 2. Relative abundance of Shredders (A), Predators (B), Gathering-Collectors (C), Filtering-Collectors (D) and Scrapers (E) in edge and center of macrophytes beds (D. lombardii and E. aquatile). First (lower line) and third (higher line) quartile, the median (bold line), upper and lower limits (dashed line) and outliers (circles). Different letters (a and b) indicate significant differences. Abundância relativa de Fragmentadores (A), Predadores (B), Coletores-Coletores (C), Coletores-Filtrantes (D) e Raspadores (E) na borda e centro $(C$ e F) em bancos de D. lombardii e E. aquatile ( $B$ e E). Primeiro (linha inferior) e terceiro quartil (linha superior), média (linha em negrito), limites superior e inferior (linha tracejada) e valores discrepantes (círculos). Letras diferentes (A e B) indicam diferenças significativas.

Eriocaulon aquatile, on the other hand, had a greater number of exclusive taxa (Dolichopodidae, Psephenidae, Perlidae, Aeshnidae and Calopterygidae) than D. lombardii (only Veliidae). This finding can be explained by the higher primary productivity of emergent macrophytes compared to submerged macrophytes (Thomaz
\& Cunha, 2010). All of these taxa are generally predators, and are thus supported by consumers, which are positively affected by primary productivity, mainly in terms of biomass (Vannote et al., 1980; Cummins, 1996; Cummins et al., 2005). However, we did not evaluate the biomass of the macroinvertebrate communities 


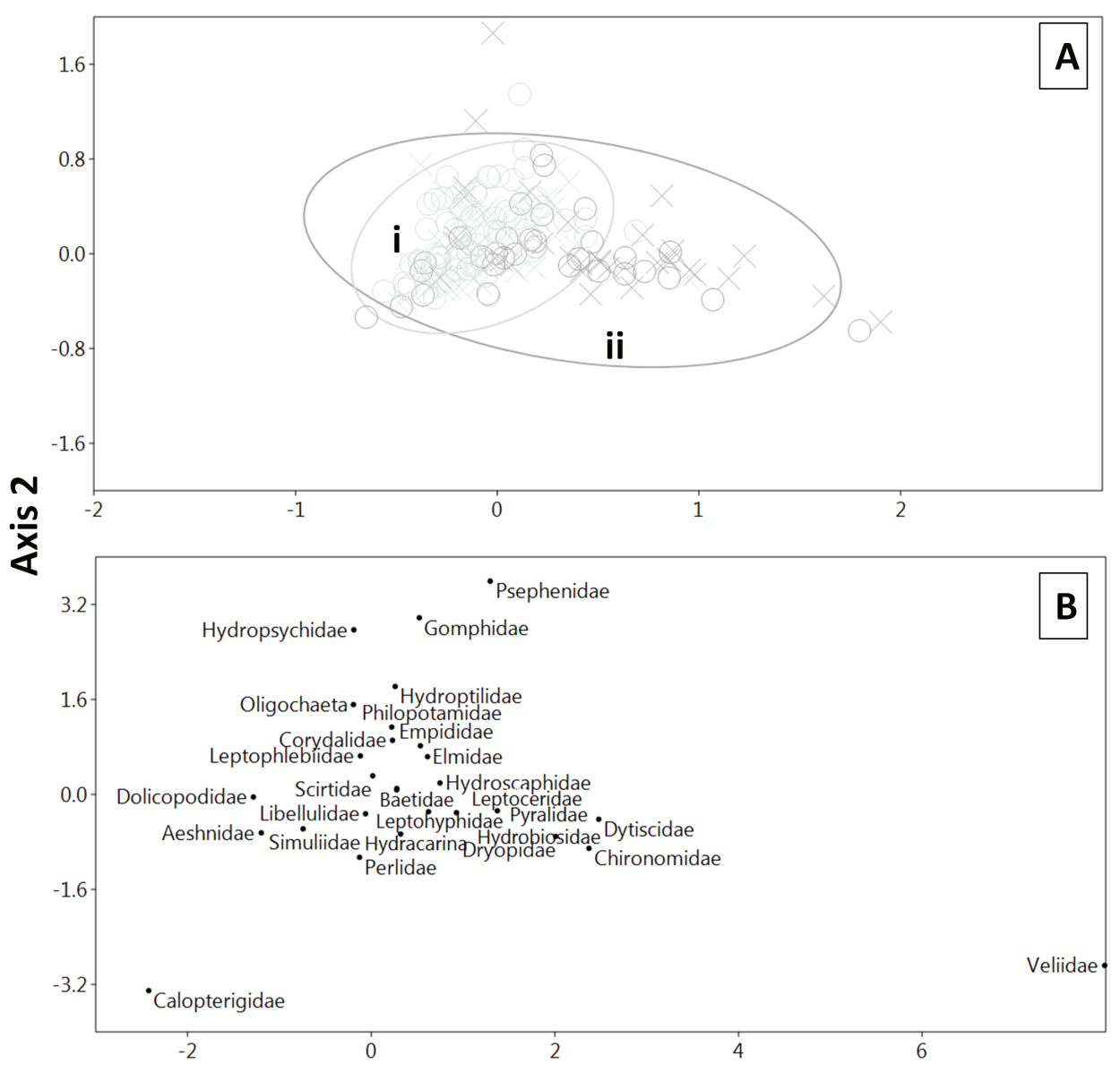

Axis 1

Figure 3. Correspondence Analysis (CA; A) of D. lombardii (dark gray) and E. aquatile (light gray) in edge (cross) and center (circle), and (B) macroinvertebrates' taxon in macrophytes species. Analise de Correspondencia (AC; A) de D. lombardii (cinza escuro; ii) e E. aquatile (cinza claro; i) entre borda (xis) e centro (circulo), e (B) taxon de macroinvertebrados nas espécies de macrofitas.

of the present study. Furthermore, the taxon Psephenidae comprises scrapers that consume biofilm in the substrate, and are positively affected by slow water current and its lower force (Vannote et al., 1980; Cummins, 1996; Cummins et al., 2005). The presence of $E$. aquatile in habitats with less current may be due to the physical and chemical characteristics of sediments, as a result of greater deposition (e.g. increase in organic matter and particle size in sediments), and water transparency (e.g. nutrient concentration and transparency), which may increase predation efficiency by these organisms (Risse-Buhl et al., 2017). Therefore, our results highlight that for emergent macrophytes, such as E. aquatile, morphological conditions of the stream (e.g. water current velocity) may influence species-specific relationships between macrophytes and macroinvertebrates by increasing primary productivity in habitats with slow water current velocity.

Greater density also helps to explain the greater predator abundance (due to increased prey), mainly in the edge (exclusive taxa Veliidae, Gomphidae, Perlidae, Aeshnidae and Calopterygidae). Higher predator density at the edge of macrophyte beds indicates increased predation efficiency compared to the center (Cummins et 
al., 2005; Warfe \& Barmuta 2004). In turn, this may increase predation pressure on filtering-collectors (higher density in the edge), and decrease it on gathering-collectors (higher density in the center), mainly in D. lombardii (Cummins et al., 2005; Hamada et al., 2014; Merritt \& Cummins 1996). This could be explained by the trophic strategy of these invertebrates (Cummins et al., 2005; Hamada et al., 2014; Kouamé et al., 2011), thus corroborating our second hypothesis.

Filtering-collectors remove fine particles of organic matter from the passing water column, which explains their greater abundance in the edge of macrophyte beds (Cummins et al., 2005; Hamada et al., 2014; Merritt \& Cummins 1996). Gathering-collectors consume fine particles of organic matter gathered from the substrate (sediment, leaf, rock, litter etc.), and thus do not require flowing water (Cummins et al., 2005; Hamada et al., 2014; Merritt \& Cummins 1996). Thus, the high density of gathering-collectors in the center of macrophyte beds may reflect a response to the high density of predation in the edge. These results highlight the importance of spatial site within the stream and within macrophyte beds (center and edge) to the abundance of FFGs in macroinvertebrate communities.

\section{CONCLUSION}

To summarize, our results show that macrophyte taxon (species) can help to drive the structure of macroinvertebrate communities in streams (higher density and richness in $D$. lombardii, mainly in the center of beds). Also, the site within macrophyte beds can drive the selection of FFGs. Therefore, we can infer that: i) the exclusion of some macrophyte species will alter the structure of macroinvertebrate communities by decreasing community diversity due to species-specific relationships; ii) different sites in macrophyte beds have different availabilities and types of food resources, highlighted by the greater density of gathering-collectors in the center and filtering-collectors in the edge (mainly in $D$. lombardii). We can also conclude that macrophyte beds are important habitats that need to be conserved to maintain the diversity of macroinvertebrates in cerrado streams.

\section{ACKNOWLEDGEMENTS}

We are grateful to the National Council of Scientific and Technological Development (CNPq project number 421288/2017-5 and FAPESC for financial support and a stipend.

\section{REFERENCES}

ALI, M. M., A. A. MAGEED \& M. HEIKAL. 2007. Importance of aquatic macrophyte for invertebrate diversity in large subtropical reservoir. Limnologica - Ecology and Management of Inland Waters, 37(2): 155-169. DOI: 10.1016/j.limno.2006.12.001

BAKER, K., M. A. CHADWICK, R. A. WAHAB \& R. KAHAR. 2016. Benthic community structure and ecosystem functions in above- and below-waterfall pools in Borneo. Hydrobiologia, 787(1): 307-322. DOI: 10.1007/ s10750-016-2975-4

BALCI, P. \& J. H. KENNEDY. 2003. Comparison of Chironomids and Other Macroinvertebrates Associated with Myriophyllum spicatum and Heteranthera dubia. Journal of Freshwater Ecology, 18(2): 235-247. DOI: 10.1080/02705060.2003.9664490

BOYERO, L., R. G. PEARSON, C. M. SWAN, C. HUI, R. J. ALBARIÑO, M. ARUNACHALAM, M. CALLISTO, J. CHARÁ, A. M. CHARÁ-SERNA, E. CHAUVET, A. CORNEJO, D. DUDGEON, A. C. ENCALADA, V. FERREIRA, M. O. GESSNER, J. F. GONÇALVES, M. A. S. GRAÇA, J. E. HELSON, J. M. MATHOOKO, B. G. MCKIE, M. S. MORETTI \& C. M. YULE. 2015. Latitudinal gradient of nestedness and its potential drivers in stream detritivores. Ecography, 38(9): 949-955. DOI: 10.1111/ecog.00982

CARVALHO, C., L. U. HEPP, C. PALMA-SILVA \& E. F. ALBERTONI. 2015. Decomposition of macrophytes in a shallow subtropical lake. Limnologica - Ecology and Management of Inland Waters, 53: 1-9. DOI: 10.1016/j.limno.2015.04.003

CHOI, J.-Y., K.-S. JEONG, G.-H. LA \& G.-J. JOO. 2014. Effect of removal of free-floating macrophytes on zooplankton habitat in shallow wetland. Knowl Managt Aquatic Ecosyst, 
414(11): 1-10. DOI: 10.1051/kmae $/ 2014023$

CRAWLEY, M. J. 2007. The R Book. John Wiley

\& Sons Ltd, England.

CHRISTOFFERSEN, K. S. 2008. Emergent and floating-leaved macrophytes as refuge for zooplankton in a eutrophic temperate lake without submerged vegetation. Hydrobiologia, 605: 113-122. DOI: 10.1007/s10750008-9324-1

CUMMINS, K. W. 1996. An introduction to the aquatic insects of North America. Kendall/Hunt Publishing Company. Dubuque. CUMMINS, K., R. MERRITT \& P. ANDRADE. 2005. The use of invertebrate functional groups to characterize ecosystem attributes in selected streams and rivers in south Brazil. Studies on Neotropical Fauna and Environment, 40(1): 69-89. DOI: 10.1080/01650520400025720

DAMANIK-AMBARITA, M., G. EVERAERT, M. FORIO, T. NGUYEN, K. LOCK, P. MUSONGE, N. SUHAREVA, L. DOMINGUEZ-GRANDA, E. BENNETSEN, P. BOETS \& P. GOETHALS. 2016. Generalized Linear Models to Identify Key Hydromorphological and Chemical Variables Determining the Occurrence of Macroinvertebrates in the Guayas River Basin (Ecuador). Water, 8(7): 297. DOI: $10.3390 / w 8070297$

DE NADAÏ-MONOURY, E., F. GILBERT \& A. LECERF. 2014. Forest canopy cover determines invertebrate diversity and ecosystem process rates in depositional zones of headwater streams. Freshwater Biology, 59(7): 1532-1545. DOI: 10.1111/fwb. 12364

DURÃES, L., F. O. ROQUE, T. SIQUEIRA, A. M. SANTOS, M. A. BORGES \& R. S. REZENDE. 2016. Simulating the role of connectivity in shaping stream insect metacommunities under colonization cycle dynamics. Ecological Modelling, 334: 19-26. DOI: 10.1016/j.ecolmodel.2016.04.020

FENOGLIO, S., N. BONADA, S. GUARESCHI, M. J. LOPEZ-RODRIGUEZ, A. MILLAN \& J. M. TIERNO DE FIGUEROA. 2016. Freshwater ecosystems and aquatic insects: a paradox in biological invasions. Biology letters, 12(4). DOI: 10.1098/rsbl.2015.1075

FERREIRA, V., J. CASTELA, P. ROSA, A. M. TONIN, L. BOYERO \& M. A. S. GRAÇA.
2016. Aquatic hyphomycetes, benthic macroinvertebrates and leaf litter decomposition in streams naturally differing in riparian vegetation. Aquatic Ecology, 50(4): 711-725. DOI: $10.1007 / \mathrm{s} 10452-016-9588-\mathrm{x}$

FERREIRA, W. R., R. LIGEIRO, D. R. MACEDO, R. M. HUGHES, P. R. KAUFMANN, L. G. OLIVEIRA \& M. CALLISTO. 2014. Importance of environmental factors for the richness and distribution of benthic macroinvertebrates in tropical headwater streams. Freshwater Science, 33(3): 860-871. DOI: 10.1086/676951

GONÇALVES, J. F., JR., R. S. REZENDE, J. FRANÇA \& M. CALLISTO. 2012. Invertebrate colonisation during leaf processing of native, exotic and artificial detritus in a tropical stream. Marine and Freshwater Research, 63(5): 428-439. DOI: $10.1071 / \mathrm{mf} 11172$

GONÇALVES, J. F., S. R. M. COUCEIRO, R. S. REZENDE, R. T. MARTINS, B. M. P. OTTONI-BOLDRINI, C. M. CAMPOS, J. O. SILVA \& N. HAMADA. 2016. Factors controlling leaf litter breakdown in Amazonian streams. Hydrobiologia, 792(1): 195-207. DOI: $10.1007 / \mathrm{s} 10750-016-3056-4$

GREENWAY, R., L. ARIAS-RODRIGUEZ, P. DIAZ \& M. TOBLER. 2014. Patterns of Macroinvertebrate and Fish Diversity in Freshwater Sulphide Springs. Diversity, 6(3): 597-632. DOI: 10.3390/d6030597

HAMADA, N., J. L. NESSIMIAN \& R. B. QUERINO. 2014. Insetos aquáticos na Amazônia brasileira: taxonomia, biologia e ecologia, vol 1. INPA, Manaus.

HARRISON, S. S. C., J. L. PRETTY, D. SHEPHERD, A. G. HILDREW, C. SMITH \& R. D. HEY. 2004. The effect of instream rehabilitation structures on macroinvertebrates in lowland rivers. Journal of Applied Ecology, 41(6): 1140-1154. DOI: 10.1111/j.0021-8901. 2004.00958.x

HEINO, J., A. S. MELO \& L. M. BINI. 2015a. Reconceptualising the beta diversity-environmental heterogeneity relationship in running water systems. Freshwater Biology, 60(2): 223-235. DOI: 10.1111/fwb.12502

HEINO, J., A. S. MELO, L. M. BINI, F. ALTERMATT, S. A. AL-SHAMI, D. G. 
ANGELER, N. BONADA, C. BRAND, M. CALLISTO, K. COTTENIE, O. DANGLES, D. DUDGEON, A. ENCALADA, E. GOTHE, M. GRONROOS, N. HAMADA, D. JACOBSEN, V. L. LANDEIRO, R. LIGEIRO, R. T. MARTINS, M. L. MISERENDINO, C. S. MD RAWI, M. E. RODRIGUES, O. ROQUE FDE, L. SANDIN, D. SCHMERA, L. F. SGARBI, J. P. SIMAIKA, T. SIQUEIRA, R. M. THOMPSON \& C. R. TOWNSEND. 2015b. A comparative analysis reveals weak relationships between ecological factors and beta diversity of stream insect metacommunities at two spatial levels. Ecology and evolution, 5(6): 1235-48. DOI: 10.1002/ece3.1439

JARDINE, T. D.. 2014. Organic matter sources and size structuring in stream invertebrate food webs across a tropical to temperate gradient. Freshwater Biology, 59(7): 1509-1521. DOI: $10.1111 /$ fwb. 12362

KOUAMÉ, M. K., M. Y. DIETOA, E. O. EDIA, S. K. DA COSTA, A. OUATTARA \& G. GOURÈNE. 2011. Macroinvertebrate communities associated with macrophyte habitats in a tropical man-made lake (Lake Taabo, Côte d'Ivoire). Knowl Managt Aquatic Ecosyst, 400(1): 1-18. DOI: $10.1051 / \mathrm{kmae} / 2010035$

LYCARIÃ̃, T. A. \& Ê. W. DANTAS. 2017. Interactions between different biological forms of aquatic macrophytes in a eutrophic tropical reservoir in Northeastern Brazil. Revista De Biologia Tropical, 65: 1095-1104.

LOBERA, G., I. MUÑOZ, J. A. LÓPEZ-TARAZÓN, D. VERICAT \& R. J. BATALLA. 2016. Effects of flow regulation on river bed dynamics and invertebrate communities in a Mediterranean river. Hydrobiologia, 784(1): 283-304. DOI: 10.1007/s10750016-2884-6

MERRITT, R. W. \& K. W. CUMMINS. 1996. An introduction to the aquatic insects of North America. Kendall/Hunt Publishing Company, Dubuque.

MORA-GÓMEZ, J., A. ELOSEGI, S. DUARTE, F. CÁSSIO, C. PASCOAL \& A. M. ROMANÍ. 2016. Differences in the sensitivity of fungi and bacteria to season and invertebrates affect leaf litter decomposition in a Mediterranean stream.
FEMS Microbiology Ecology, 92(8): fiw 121. DOI: 10.1093/femsec/fiw121

MYKRA, H., J. AROVIITA, H. HAMALAINEN, J. KOTANEN, K.-M. VUORI \& T. MUOTKA. 2008. Assessing stream condition using macro invertebrates and macrophytes: concordance of community responses to human impact. Fundamental and Applied Limnology, 172(3): 191-203. DOI: 10.1127/ 1863-9135/2008/0172-0191

OKSANEN, J., R. KINDT, P. LEGENDRE, B. O'HARA, G. L. SIMPSON, P. SOLYMOS, M. H. H. STEVENS \& H. WAGNER. 2008. Adonis function Vegan: Community Ecology Package R package. Version 113-1. 15-20.

OKSANEN, J., F. G. BLANCHET, R. KINDT, P. LEGENDRE, P. R. MINCHIN, R. B. O'HARA, G. L. SIMPSON, P. SOLYMOS, M. HENRY, H. STEVENS \& H. WAGNER. 2013. Community Ecology Package: Ordination, Diversity and Dissimilarities. Version 2.0-8.

PADIAL, A. A., F. CESCHIN, S. A. DECLERCK, L. DE MEESTER, C. C. BONECKER, F. A. LANSAC-TOHA, L. RODRIGUES, L. C. RODRIGUES, S. TRAIN, L. F. VELHO \& L. M. BINI. 2014. Dispersal ability determines the role of environmental, spatial and temporal drivers of metacommunity structure. Plos One 9(10): e111227. DOI: 10.1371/journal.pone.0111227 PÉREZ, G. P. 1988. Guía para el estudio de los macroinvertebrados acuáticos del departamento de Antioquia. Editorial Presencia Ltda, Bogotá.

QUINTÃO, J. M. B., R. S. REZENDE \& J. F. G. JÚNIOR. 2013. Microbial effects in leaf breakdown in tropical reservoirs of different trophic status. Freshwater Science, 32(3): 933-950. DOI: 10.1899/12-112.1

REZENDE, R. D. S., G. F. M. LEITE, A. K. S. DE-LIMA, L. A. B. D. SILVA FILHO, C. V. C. CHAVES, A. C. H. PRETTE, J. S. FREITAS \& J. F. GONÇALVES JÚNIOR. 2015. Effects of density and predation risk on leaf litter processing by Phylloicus sp. Austral Ecology, 40(6): 693-700. DOI: 10.1111/aec.12236

REZENDE, R. D. S., M. A. S. GRAÇA, A. M. SANTOS, A. O. MEDEIROS, P. F. SANTOS, Y. R. NUNES \& J. F. G. JUNIOR. 2016. 
Organic Matter Dynamics in a Tropical Gallery Forest in a Grassland Landscape. Biotropica, 48(3): 301-310. DOI: 10.1111/btp.12308

REZENDE, R. S., A. M. SANTOS, C. HENKE-OLIVEIRA \& J. F. GONÇALVES JR. 2014b. Effects of spatial and environmental factors on benthic a macroinvertebrate community. Zoologia (Curitiba), 31(5): 426-434. DOI: 10.1590/s1984-46702014005000001

REZENDE, R. S., M. M. PETRUCIO \& J. F. GONÇALVES, JR. 2014a. The Effects of Spatial Scale on Breakdown of Leaves in a Tropical Watershed. Plos One 9(5): e97072. DOI: 10.1371/journal.pone.0097072

RISSE-BUHL, U., C. MENDOZA-LERA, H. NORF, J. PEREZ, J. POZO \& J. SCHLIEF. 2017. Contrasting habitats but comparable microbial decomposition in the benthic and hyporheic zone. Science of the Total Environment, 605-606: 683-691. DOI: 10.1016/j. scitotenv.2017.06.203

RODRIGUEZ-LOZANO, P., M. RIERADEVALL \& N. PRAT. 2016. Top predator absence enhances leaf breakdown in an intermittent stream. Science of the Total Environment, 572(1): 1123-1131. DOI: 10.1016/j. scitotenv.2016.08.021

ROSA, J., V. FERREIRA, C. CANHOTO \& M. A. S. GRAÇA. 2013. Combined effects of water temperature and nutrients concentration on periphyton respiration - implications of global change. International Review of Hydrobiology, 98(1): 14-23. DOI: 10.1002/iroh.201201510

SYCHRA, J., Z. ADÁMEK \& K. PETŘIVALSKÁ. 2010. Distribution and diversity of littoral macroinvertebrates within extensive reed beds of a lowland pond. Annales de Limnologie International Journal of Limnology, 46(4): 281-289. DOI: 10.1051/limn/2010026

TESSIER, C., A. CATTANEO, B. PINEL-ALLOUL, C. HUDON \& D. BORCARD. 2008. Invertebrate communities and epiphytic biomass associated with metaphyton and emergent and submerged macrophytes in a large river. Aquatic Sciences, 70 (1): 10-20.

THOMAZ, S. M. \& E. R. D. CUNHA. 2010. The role of macrophytes in habitat structuring in aquatic ecosystems: methods of measurement, causes and consequences on animal assemblages' composition and biodiversity. Acta Limnologica Brasiliensia, 22 (1): 218-236.

TRONSTAD, L. M., S. HOTALING, J. C. BISH, S. R. LEATHER \& G. SAHLEN. 2016. Longitudinal changes in stream invertebrate assemblages of Grand Teton National Park, Wyoming. Insect Conservation and Diversity 9(4): 320-331. DOI: 10.1111/icad.12169

VANNOTE, R. L., G. W. MINSHALL, K. W. CUMMINS, J. R. SEDELL \& C. E. CUSHING. 1980. River Continuuum Concept. Canadian Journal of Fisheries and Aquatic Sciences, 37 (1): 130-137.

WARFE, D. M. \& L. A. BARMUTA. 2004. Habitat structural complexity mediates the foraging success of multiple predator species. Oecologia, 141(1): 171-8. DOI: 10.1007/s00442-0041644-x

WARFE, D. M. \& L. A. BARMUTA. 2006. Habitat structural complexity mediates food web dynamics in a freshwater macrophyte community. Oecologia, 150(1): 141-154. DOI: $10.1007 / \mathrm{s} 00442-006-0505-1$.
Con el apoyo de:
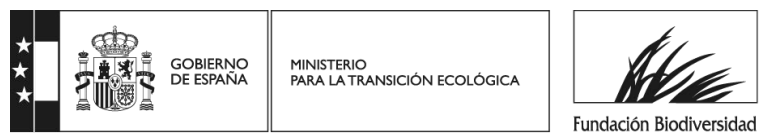